\title{
Rare Association of Renal Echinococcosis with Oncocytoma
}

\author{
Tanushri Mukherjee* \\ Department of Pathology, Command Hospital, India
}

Submission: July 24, 2017; Published: August 30, 2017

*Corresponding author: Tanushri Mukherjee, Department of Pathology, Command Hospital, Chandimandir, India,

Email: tanujamukherjee@yahoo.com

\begin{abstract}
This is a review to highlight the occurrence of a common parasitic lesion at a rare site that is kidney and that too associated with a renal tumor and is not reported in the world literature so far. Echinococcosis in kidney occurs in 2-3\% of all cases. Renal oncocytomas are 5-7\% of all renal tumors and they originate from distal renal tubules.
\end{abstract}

Keywords: Echinococcosis; Oncocytoma

Introduction

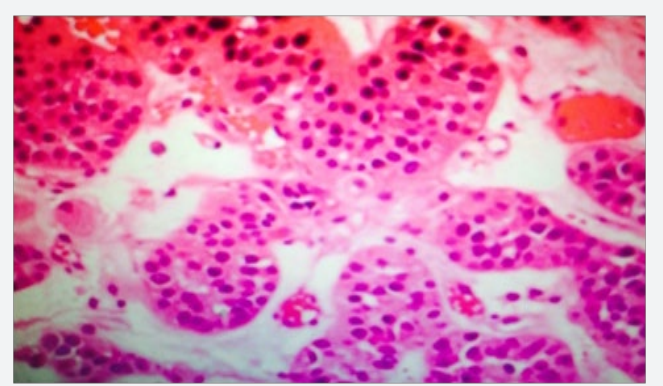

Figure 1: Microphotograph showing oncytoma in kidney with large eosinophilic cells with granular cytoplasm.

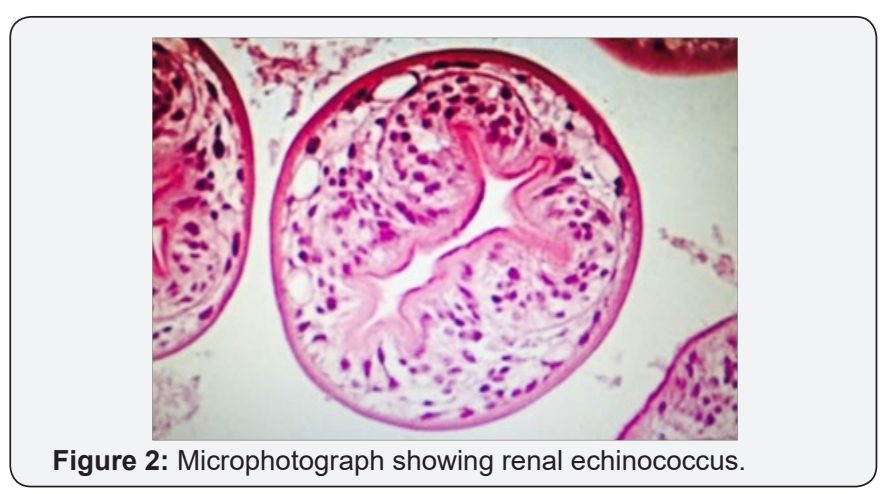

Occurrence of a common parasitic lesion at a rare site that is kidney and that too associated with a renal tumor is not reported in the world literature so far. Echinococcosis in kidney occurs in $2-3 \%$ of all cases [1-3]. Renal oncocytomas are $5-7 \%$ of all renal tumors and they originate from distal renal tubules [4-8]. 70-year man with a renal mass detected on Computed tomography measuring $8 \times 4 \times 3 \mathrm{~cm}$, associated with the left kidney, Left nephrectomy was performed. While slicing the specimen pus exuded out and a tan colored cystic solid mass. In gross appearance, the tumor was mahogany brown, well circumscribed and contained a central scar. Tumor was cystic solid with variegated irregular cyst wall and was measuring $7 \times 4 \times 3 \mathrm{cms}$ with a purulent exudate on the cut surface (Figure 1). The histology was interesting showing parasite echinococcus (Figure 2) with all three layers of the cyst i.e. pericyst, ectocyst and endocyst (germinal layer) containing daughter cysts, scolices and hooklets. Echinococcosis is a parasite borne disease. Renal echinococcosis caused by E multilocularis [1-3].

The tumor was renal oncocytoma with the cells which appeared to be round to polygonal with abundant granular eosinophilic cytoplasm, a regular round nucleus, and a central nucleolus Surgery that is nephrectomy is the treatment of choice in renal hydatid cyst which is diagnosed preoperatively. Pre and postoperative one-month courses of Albendazole lessens the chance of anaphylaxis and decrease the tension in the cyst wall (thus reducing the risk of spillage during surgery) and to reduce the recurrence rate [4-7]. IHC was not performed due to the characteristic histology. Vimentin, CK7, CD10, and

Hale's colloidal iron can be used for the differential diagnosis of problematic tumors of kidney like concentional renal cell and chromophobe renal cell carcinoma which may pose differential problems with oncocytoma. Chromophobe Renal cell carcinoma is Vimentin, CD10 negative, CK7-positive and positive diffuse fine reticular cytoplasmic pattern of Hale's colloidal iron; 
Oncocytomais Vimentin, CK7, CD10-negative and Hale's colloidal iron -negative; Conventinal renal cell carcinoma CK7-negative, Vimentin, CD10-positive and Hale's colloidal iron -negative [7].

\section{Discussion}

Renal oncocytoma is a benign solitary lesion diagnosed incidentally however, it may metastasize or infiltrate peripheral renal tissues. In this case renal oncocytoma was associated with a parasitic cyst of echinococus which is a rare association. Renal Echinococcosisor the hydatid cyst of the kidney is a very rare condition caused by the Echinococcus. Granulosus and Kidney is the third commonest organ involved after the liver and the lungs. The incidence of renal involvement is about $2 \%$ of all hydatid disease in man and isolated renal involvement is very rare. Management is mainly surgery to prevent cyst rupture. Conservative management with oral Albendazole is successful in only $40 \%$ of cases. Surgical management consists of various options like partial and total excision. Partial excision should be preceded by the injection of scolicidal agents into the cyst which include 20\% hypertonic saline, Chlorhexidine, 80\% Ethanol, $0.5 \%$ Cetrimide, $3 \% \mathrm{H}_{2} \mathrm{O}_{2}$ and $0.5 \%$ Silvernitrate. Patient has to be operated under the cover of antihistaminics and steroids for the fear of anaphylaxis if cyst rupture occurs during surgery.

\section{Conclusion}

This review article is to highlight the association of renal echinococcosis with oncocytoma.

\section{References}

1. Ritesh M, Shrinivas N, Anup K Kundu (2008) Primaryhydatid cyst of kidney and ureter with gross hydatiduria: A case report and evaluation of radiological features. Indian J Urol 24(1): 116-117.

2. Von Sinner WN, Hellstrom M, Kagevi I, Norlen BJ (1993) Hydatid disease of the urinary tract. J Urol 149: 577-580.

3. Pedrosa I, Saiz A, Arrazola L, Ferreiros J, Pedrosa CS (2000) Hydatid disease: Radiologic and pathologic features and complications. Radiographics 20(3): 795-817.

4. Amin MB, Crotty TB, Tickoo SK, Farrow GM (1997) Renal oncocytoma: A reappraisal of morphologic features with clinicopathologic findings in 80 cases. Am J Surg Pathol 21(1): 1-12.

5. Perez OB, Hamed G, Campbell S, Erlandson RA, Russo P, et al. (1997) Renal oncocytoma: a clinicopathologic study of 70 cases. Am J Surg Pathol 21(8): 871-883.

6. Lieber MM (1990) Renal oncocytoma: prognosis and treatment. Eur Urol 18(2): 17-21.

7. Geramizadeh B, Ravanshad M, Rahsaz M (2008) Useful markers for differential diagnosis of oncocytoma, chromophobe renal cell carcinoma and conventional renal cell carcinoma. Indian J Pathol Microbiol 51(2): 167-171.
Your next submission with Juniper Publishers will reach you the below assets

- Quality Editorial service

- Swift Peer Review

- Reprints availability

- E-prints Service

- Manuscript Podcast for convenient understanding

- Global attainment for your research

- Manuscript accessibility in different formats ( Pdf, E-pub, Full Text, Audio)

- Unceasing customer service

Track the below URL for one-step submission https://juniperpublishers.com/online-submission.php 